JOSIANA CRISTINA RIBEIRO

ULTRASTRUCTURE AND CYTOCHEMISTRY OF COLLETERS IN APOCYNACEAE

SÃO PAULO - 2017 
Josiana Cristina Ribeiro

Ultrastructure and cytochemistry of colleters in Apocynaceae

Ultraestrutura e citoquímica de coléteres de Apocynaceae

Dissertação apresentada ao
Instituto de Biociências da
Universidade de São Paulo, para a
obtenção do título de Mestre em
Ciências, na área de Botânica.

Orientação: Prof. Dr. Diego Demarco

São Paulo - 2017 
Ribeiro, Josiana Cristina 2017

Ultrastructure and cytochemistry of colleters in Apocynaceae 55 Páginas

Dissertação (Mestre) - Instituto de Biociências da Universidade de São Paulo, Departamento de Botânica.

\section{COMISSÃO JULGADORA}

Prof. Dr.

Prof. Dr.

Prof. Dr. Diego Demarco 
"Tudo aprendemos juntos; juntos aprendemos a elevar-nos sobre nós, e a sorrir, sem nuvens, para baixo, com límpidos olhos, desde remotas paragens, quando a nossos pés se desvanecem como névoa vaporasa, a imposição, o fim e o erro."

Friendrich Nietzsche - Assim falou Zaratustra

"Poco a poco he descubierto el secreto de mi arte. Se trata de la meditación sobre la naturaleza, en la expresión de un sueño que siempre está inspirado en la realidad."

Henri Matisse

"Se não houver frutos, valeu a beleza das flores; se não houver flores, valeu a sombra das folhas; se não houver folhas, valeu a intenção da semente." 


\section{AGRADECIMENTOS}

À agência de fomento FAPESP pela concessão de bolsa de pesquisa $(2015 / 05590-6)$

Ao Programa de Pós-gradução do Instituto de Biociências da Universidade de São Paulo, ao Laboratório de Anatomia Vegetal, ao Laboratório Central de Aquisição de Imagens e Microscopia (CAIMi) e aos técnicos Irwandro Pires, Gisele Costa e Tássia Santos, por toda a infraestrutura e auxílio na preparação dos materiais estudados.

Especialmente ao meu professor e orientador Diego Demarco pela excelente orientação, por todos os ensinamentos, por estar sempre pronto a me ouvir e a esclarecer minhas dúvidas, pela oportunidade, confiança e paciência.

À toda a equipe de estudo Bethi, Ellen, Érika, Gisele, Isabella, Karina, Larissa, Maria Camila, Mariana, Natalie, Rebeca e Thália.

Aos amigos queridos Jonas Fernandes Ana Sigrist e Larissa Moser por me acolherem com tanto carinho e por ter sido a minha família nesse tempo que passei em São Paulo.

E principalmente a minha família que sempre me apoiou e me incentivou nos meus estudos e nas minhas escolhas. Em especial a minha mãe, Joana P. da Veiga, que sempre esteve do meu lado me dando amor, carinho e atenção nos momentos felizes e difíceis dessa trajetória.

À Deus por ter colocado em meu caminho todas essas pessoas especiais que direto ou indiretamente coloboraram com a minha formação. 
$\begin{array}{ll}\text { ABSTRACT } & 1\end{array}$

$\begin{array}{ll}\text { RESUMO } & 3\end{array}$

GENERAL INTRODUCTION

APOCYNACEAE

$\begin{array}{lr}\text { COLLETERS } & 7\end{array}$

$\begin{array}{lr}\text { Distribution } & \mathbf{8}\end{array}$

$\begin{array}{lr}\text { Anatomy } & \mathbf{8}\end{array}$

Secretion 9

Origin

LITERATURE CITED

SECRETORY PATTERNS IN COLLETERS OF APOCYNACEAE 20

$\begin{array}{lr}\text { INTRODUCTION } & 21\end{array}$

MATERIAL AND METHODS

$\begin{array}{lr}\text { RESULTS } & 25\end{array}$

DISTRIBUTION

MORPHOLOGY 25

ANATOMY

ULTRASTRUCTURE

FIGURES

$\begin{array}{ll}\text { DISCUSSION } & 43\end{array}$

SECRETORY MACHINERY $\quad \mathbf{4 4}$

SECRETION RELEASE $\quad 46$

LITERATURE CITED 


\section{Abstract}

The colleters of Apocynaceae are glands related to different types of protection of vegetative and floral meristems through the production of mucilage or a mixture of many different compounds. Although several anatomical papers have shown histological and histochemical aspects of colleters of the family, almost nothing is known about the secretory process of the cells of this gland. In this paper we studied two types of colleters that occur in the family: what produces exclusively mucilaginous secretion and what produces mucilage and lipophilic compounds, being analyzed in two species for each type of colleter. The secretory epidermis of the colleters of Allamanda schottii and Blepharodon bicuspidatum presents a large amount of dictiosomes and endoplasmic reticulum, a dispersed vacuoma composed of small vacuoles with fibrilar osmiophilic material, leucoplasts with large amount of starch and few thylakoids, as well as large mitochondria. The mode of secretion release is granulocrine and the exudate crosses the cuticle without breaking it by projections of pectin reaching the surface. The secretory cells of the colleters of Mandevilla splendens and Peplonia axillaris have completely different ultrastructure and secretion from those of Allamanda schottii and B. bicuspidatum. Plastids and mitochondria are observed, as well as a profusion of dictiosomes and their vesicles in association with the rough endoplasmic reticulum near the cell membrane. The secretion is mainly observed in the cisterns and vesicles of the 
trans face of the dictiosomes, indicating the production of a great amount of mucilage. The mechanism of secretion release is also granulocrine, but the secretion is temporarily accumulated in a large periplasmic space before crossing the cell wall and the cuticle. Two distinct patterns of secretion production and release were found in the colleters of Apocynaceae that are related to the composition of the secretion and not to the group to which the species analyzed belong. Although the colleters in the family are histologically similar, the present paper demonstrates a metabolic and subcellular variability until then unknown to the group.

Key-words: Apocynaceae, foliar colleters, cytochesmistry, secretory process, release mode. 
Resumo

Os coléteres de Apocynaceae são glândulas relacionadas a diferentes tipos de proteção de meristemas vegetativos e florais através da produção de mucilagem ou uma mistura de muitos compostos distintos. Apesar de vários trabalhos anatômicos terem demonstrado aspectos histológicos e histoquímicos de coléteres da família, não se sabe quase nada sobre o processo secretor das células desta glândula. Neste trabalho estudamos dois tipos de coléteres que ocorrem na família: o que produz secreção exclusivamente mucilaginosa e o que produz mucilagem e compostos lipofilicos, sendo analisada em duas espécies para cada tipo de coléter. A epiderme secretora dos coléteres de Allamanda schottii e Blepharodon bicuspidatum apresenta grande quantidade de dictiossomos e retículo endoplasmático, um vacuoma disperso composto por pequenos vacúolos com material osmiofílico fibrilar, leucoplastos com grande quantidade de amido e poucos tilacóides, além de mitocôndrias grandes. O modo de liberação da secreção é granulócrino e o exsudato atravessa a cutícula sem rompê-la por meio de projeções de pectina que alcançam a superfície. As células secretoras dos coléteres de Mandevilla splendens e Peplonia axillaris possuem ultraestrutura e secreção e completamente distintos dos de Allamanda schotti e B. bicuspidatum. Observam-se plastídeos e mitocôndrias, além de uma profusão de dictiossomos e de suas vesículas em associação ao retículo 
endoplasmático rugoso próximo à membrana plasmática. A secreção é principalmente observada nas cisternas e vesículas da face trans dos dictiossomos, indicando a produção de grande quantidade de mucilagem. 0 mecanismo de liberação da secreção também é granulócrino, mas a secreção é temporariamente acumulada em um amplo espaço periplasmático, antes de atravessar a parede celular e a cutícula. Dois padrões distintos de produção e liberação da secreção foram encontrados nos coléteres de Apocynaceae que estão relacionados à composição da secreção e não ao grupo ao qual as espécies analisadas pertencem. Embora os coléteres na família sejam histologicamente semelhantes, 0 presente trabalho demonstra uma variabilidade metabólica e subcelular até então desconhecida para o grupo.

Palavras-chave: Apocynaceae, coléteres foliares, citoquímica, processo secretor, modo de liberação. 


\section{General Introduction}

Among the various secretory structures present in vegetative and/or reproductive organs of eudicots, the colleters stand out as glands whose secretion permeates and protects the meristems and organs in development (Fahn 1979, Thomas 1991, Ribeiro et al. 2017). Structurally, the colleters can be multicellular trichomes, vascularized or non-vascularized emergences (Fahn, 1979, 1990, Thomas 1991, Lacchia et al. 2016). The concept of colleter is functional and there is no relation to its structure. Due to this concept and structural similarity between colleters and other secretory structures, some authors have already described them as extrafloral nectaries and resin glands (Arekal \& Ramakrishna 1980, Inamdar et al. 1985, Mohan \& Inamdar 1986, Subramanian et al. 1989, Thomas 1991). Although these descriptions are mistaken in relation to the typification of the gland, they were based on structural and/or histochemical data, a fact that indicates the diversity of compounds that can be produced by this glandular type and that, only with a analysis of its position, period of secretory activity, composition and function of the secretion, it is possible to identify the structure correctly as a colleter (Ribeiro et al. 2017).

According to Thomas (1991), the colleters are present in the adaxial face of different organs of around 60 families and in four of the five families of the order Gentianales, such as Apocynaceae, Gentianaceae, Loganiaceae and 
Rubiaceae. In general, in Gentianales, the foliar colleters usually occur on the nodes or stipules (Solereder 1908, Thomas 1991). Rubiaceae stands out for presenting the most derivative morphological types of colleters, which can be classified as conical emergences with or without stalk and eventually trichomes (Thomas \& Dave 1991).

\section{Apocynaceae}

Apocynaceae is one of the largest and most representative families of angiosperms, containing five subfamilies: Rauvolfioideae Kostel., Apocynoideae

Burnett, Periplocoideae R.Br. ex Endl., Secamonoideae Endl. e Asclepiadoideae R. Br. Ex Burnett (Endress \& Bruyns 2000, Endress 2004, Simões et al. 2010); 25 tribes and 49 subtribes, counting on about 366 genera and approximately 5100 species (Endress 2004, Endress et al. 2014).

In Brazil, this family is currently represented by about 90 genera and approximately 850 species (Souza \& Lorenzi 2005) distributed in several vegetation formations, being trees, shrubs, lianas or herbs, having in common the presence of latex in their organs. The leaves are simple, opposite, eventually alternate (Thomas \& Dave 1991, Marcondes-Ferreira 1999, Judd et al. 2002, Simpson 2006) and have stipules modified in colleters in several species (Capelli et al. 2017). The family stands out for presenting the most elaborate flowers among the eudicots (Kunze 1991, Endress 2016) and the largest number of gland types in the same structure among the angiosperms (Demarco 2017a). 
Many floral secretory structures of Apocynaceae are involved in the production of different compounds of secondary metabolism that play a role in defense or are related to pollination, such as: colleters, glandular trichomes, laticifers, secretory idioblasts, nectaries (primary and secondary), osmophores, style head, tapetum, staminal wing gland, extracarpelar compitum, stylar canal and obturator (Fallen 1986, Vogel 1990, Kunze 1991, 1995, 1997, 1999, Thomas 1991, Appezzato-da-Glória \& Estelita 1997, 2000, Galetto 1997, Torres \& Galetto 1998, Sennblad et al. 1998, Lin \& Bernardello 1999, Rio et al. 2002, 2005, Vieira \& Shepherd 2002, Rio \& Kinoshita 2005, Demarco et al. 2006, Simões et al.2006, 2007, Gomes et al. 2008, Castro \& Demarco 2008, Demarco 2017a, b).

\section{Colleters}

Morphologically, the colleters of this family can be stalked or sessile, whose secretory portion is elongated and conical (Demarco 2005, 2017a, Barreiro \& Machado 2007, Canaveze \& Machado 2015). They vary morphologically and may be of standard type, bipartite, sessile and bipartite sessile (Martins 2012). Standard colleters were recorded for Asclepias curassavica, Chloropetalum denticulatum, Fischeria stellata, Peplonia axillaris, Oxypetalum banksii (Demarco 2008), Temnadenia violacea (Martins et al. 2010), Secondatia densiflora (Martins et al. 2013) and for Tabernaemontana catharinensis (Canaveze \& Machado 2015) which also presented bifurcated, trifurcated and sessile types as in Blepharodon bicuspidatum (Demarco 2005). 
Despite this morphological diversity, standard colleters are predominant among members of Apocynaceae (Thomas 1991, Rio et al. 2002).

\section{Distribution}

The occurrence of colleters was recorded in 67 of the 366 genera of Apocynaceae and are mentioned in the taxonomic descriptions of members of the five subfamilies (Woodson \& Moore 1938, Rao \& Ganguli 1963, Ramayya \& Bahadur 1968, Fjell 1983, Dave et al. 1987, Thomas et al. 1989, Thomas \& Dave 1989a,b, 1991, Thomas 1991, Appezzato-da-Glória \& Estelita 2000, Endress \& Bruyns 2000, Canaveze \& Machado 2015, Endress et al. 2014, Demarco 2017a). Despite several records on the occurrence of colleters in Apocynaceae, these structures may be absent in some genera (Endress \& Bruyns 2000, Demarco 2005). Both the aspect and the distribution of colleters have a great taxonomic relevance in Apocynaceae and were mentioned in the taxonomic descriptions of the five subfamilies (Sennblad et al. 1998, Endress \& Bruyns 2000).

Anatomy

The secretory portion is formed by a uniseriate epidermis composed by columnar cells arranged in palisade covered by a fine cuticle and a nonsecreting parenchymatic axis, whose cells are elongated longitudinally (Thomas \& Dave 1989b). However, some species have structural variations and may present a phenolic hypoderm, which gives a dark color to the foliar colleters as in Matelea, or a bisseriate secretory epidermis in some regions as observed in 
Allamanda and Roupelia (Ramayya \& Bahadur 1968, Thomas et al. 1989b, Demarco 2008). In addition, secretory idioblasts and laticifers can be found in the central axis of colleters in several genera (Barros 1986/1988, Subramanian et al. 1989, Appezzato-da-Glória \& Estelita 2000, Demarco 2008).

Most species of Apocynaceae have non-vascularized colleters (Demarco 2017a) but vascularized colleters were recorded in Dregea, Mandevilla and Prestonia (Arekal \& Ramakrishna 1980, Appezzato-da-Glória \& Estelita 2000, Rio et al. 2002). In Mandevilla, foliar colleters may or may not be vascularized, depending on the proximity to the vascular system of the leaf (Appezzato-daGlória \& Estelita 2000), and vascular tissues were observed in Temnadenia violacea (Martins et al. 2010). According to Thomas and Dave (1991), the presence of vasculature is an important evolutionary step for colleters.

\section{Secretion}

The secretion of the colleters is viscous and can be constituted by mucilage, resin (Thomas 1991) or a mixture of mucilage and lipophilic substances (Fahn 1979, 1990, Castro \& Demarco 2008, Demarco 2017a, Ribeiro et al. 2017). Histochemical studies have shown that the colleters of Apocynaceae secrete mainly mucilage, which involves the apex and organs in the early stages of development, protecting them against desiccation, besides lipids that prevent the proliferation of fungi and can immobilize small phytophagous (Ribeiro et al. 2017). 
The presence of lipophilic compounds was verified in species of Allamanda, Alstonia, Asclepias, Blepharodon, Colotropis, Chloropetalum (=Matelea), Mandevilla, Fischeria, Oxypetalum, Plumeria and Tabernaemontana (Mohan \& Inamdar 1986, Kuriachen \& Dave 1989, Thomas \& Dave 1989a,b, Appezzato-da-Glória \& Estelita 2000, Canaveze \& Machado 2015, Ribeiro et al. 2017). The production of lipophilic compounds varies depending on the species analyzed. In Asclepias, Blepharodon, Chloropetalum, Fischeria, Oxypetalum and Plumeria, they are continuously produced from the initial to the final stage of development (Mohan \& Inamdar 1986, Demarco 2005, Castro \& Demarco 2008, Ribeiro et al. 2017). However, in Allamanda, secretion of the lipophilic fraction is higher in young colleters and ceases mature ones (Thomas \& dave 1989a), and in Mandevilla, they are released in a second secretory phase, after colleters cease the production of mucilage (Appezzatoda-Glória \& Estelita 2000). This second secretory phase was also recorded in Forsteronia, in which the cells begin to accumulate phenolic compounds (Rio 2006).

Origin

Foliar colleters are already initiated in the first node and in the adaxial region of the foliar primordium (Demarco 2005). In some cases, the colleters are modified stipules. Ontogenetic analyses of laminar and petiolar colleters demonstrate that they are simply enations of restricted leaf portions but interpetiolar colleters derive from two groups of meristematic cells that develop 
from the base of the petiole (stipules) at the beginning of the leaf primordium development (Capelli et al. 2017). In all twelve genera of Apocynaceae studied by these authors, the stipules grow like two meristematic masses one towards the other and merge into a stipular arch from which the interpetiolar colleters originate.

This study aims to analyze and describe ultrastructurally the colleters of Apocynaceae verifying the similarities and differences in relation to the production and release of the different compounds that constitute their secretion. 


\section{Literature Cited}

APPEZZATO-DA-GLÓRIA B \& ESTELITA MEM. 1997. Laticifers systems in Mandevilla illustris and $M$. velutina Apocynaceae. Acta Societatis Botanicorum Poloniae 66: 301-306.

APPEZZATO-DA-GLÓRIA B \& ESTELITA MEM. 2000. Development, structure and distribution of colleters in Mandevilla illustris and $M$. velutina (Apocynaceae). Revista Brasileira de Botânica 23: 113-120.

AREKAL GD \& RAMAKRISHNA TM. 1980. Extrafloral nectaries of Calotropis gigantea and Wattakaka volubilis. Phytomorphology 30: 303-306.

BARREIRO DP \& MACHADO SR. 2007. Coléteres dendróides em Alibertia sessilis (Vell.) K. Schum., uma espécie não-nodulada de Rubiaceae. Revista Brasileira de Botânica 30: 387-399.

BARROS CF. 1986/1988. Himatanthus lancifolius (Muell. Arg.) Woodson (Apocynaceae). Anatomia foliar. Rodriguésia 64/66: 25-31.

CANAVEZE Y \& MACHADO SR. 2015. Leaf colleters in Tabernaemontana catharinensis (Apocynaceae, Rauvolfioideae): structure, ontogenesis, and cellular secretion. Botany 93: 287-296.

CAPELLI NV, RODRIGUES BA \& DEMARCO D. 2017. Stipules in Apocynaceae: an ontogenetic perspective. AoB Plants 9: plw083. 
CASTRO M de M \& DEMARCO D. 2008. Phenolic compounds produced by secretory structures in plants: a brief review. Natural Product Communications 3: 1273-1284.

DAVE Y, THOMAS V \& KURIACHEN PM. 1987. Structure and development of colleters in Aganosma caryophyllata G. Don. Pakistan Journal of Botany 19: 243-248.

DEMARCO D. 2005. Estruturas secretoras florais e coléteres foliares em espécies de cerrado de Aspidosperma Mart. E Blepharodon Decne. (Apocynaceae s.l.). Campinas, Dissertação de Mestrado, Instituto de Biologia, Universidade Estadual de Campinas.

DEMARCO D. 2008. Glândulas de órgãos vegetativos aéreos e florais de espécies de Asclepiadeae (R.Br.) Duby (Asclepiadoideae, Apocynaceae) de Mata Atlântica do Estado de São Paulo. Campinas, Tese de Doutorado, Instituto de Biologia, Universidade Estadual de Campinas.

DEMARCO D. 2017a. Floral glands in asclepiads: structure, diversity and evolution. Acta Botanica Brasilica 31(3): 477-502.

DEMARCO D. 2017b. Staminal wing gland: a novel secretory structure of asclepiads. Botany 95(7): 763-772.

DEMARCO D KINOSHITA LS \& CASTRO M de M. 2006. Laticíferos articulados anastomosados - novos registros para Apocynaceae. Revista Brasileira de Botânica 29: 133-144.

ENDRESS ME. 2004. Apocynaceae: Brown and now. Telopea 10: 525-541. 
ENDRESS ME \& BRUYNS PV. 2000. A Revised Classification of Apocynaceae s.l. The Botanical Review 66: 1-56.

ENDRESS ME, LIEDE-SCHUMANN S \& MEVE U. 2014. An updated classification for Apocynaceae. Phytotaxa 3: 175-194.

ENDRESS PK. 2016. Development and evolution of extreme synorganization in angiosperm flowers and diversity: a comparison of Apocynaceae and Orchidaceae. Annals of Botany 117: 749-767.

FAHN A. 1979. Secretory tissues in plants. London, Academic Press.

FAHN A. 1990. Plant anatomy. 4th ed., Oxford, Pergamon Press.

FALLEN ME. 1986. Floral structure in the Apocynaceae: morphological, functional and evolutionary aspects. Botanishe Jahrbücher für Systematik 106: 245-286.

FJELL I. 1983. Anatomy of the xeromorphic leaves of Allamanda neriifolia, Thevetia peruviana and Vinca minor (Apocynaceae). Nordic Journal of Botany 3: 383-392.

GALETTO L. 1997. Flower structure and nectar chemical composition in three Argentine Apocynaceae. Flora 192: 197-207.

GOMES SM, KINOSHITA LS \& CASTRO M de M. 2008. Hemisincarpia e nectário apendicular enfocados através de ontogênese floral em Mandevilla velame (A. St.-Hil.) Pichon, Apocynoideae. Revista Brasileira de Botânica 31: 81-93. 
INAMDAR JA, MOHAN JSS \& SUBRAMANIAN RB. 1985. Extrafloral nectaries of Holarrhena antidysenterica (L.) Wall ex G. Don. Development, ultrastructure and secretion. Trends in Plant Research. 137-148.

JUDD WS, CAMPBELL CS, KELLOGG EA, STEVENS PF \& DONOGHUE MJ. 2002. Plant systematics: a phylogenetic approach. 2nd edn. Sunderland, Sinauer Associates.

KUNZE H. 1991. Structure and function in asclepiad pollination. Plant Systematics and Evolution 176: 227-253.

KUNZE H. 1995. Floral morphology of some Gonolobeae (Asclepiadaceae). Botanische Jahrbücher für Systematik 117: 211-238.

KUNZE H. 1997. Corona and nectar system in Asclepiadinae (Asclepiadaceae). Flora 192: 175-183.

KUNZE H. 1999. Pollination ecology in two species of Gonolobus (Asclepiadaceae). Flora 194: 309-316.

KURIACHEN PM \& DAVE Y. 1989. Structural, developmental and histochemical studies in the colleters of Calotropis L. (Asclepiadaceae). Journal of Phytological Research 2: 7-14.

LACCHIA APS, TOLKE EEAD, CARMELLO-GUERREIRO SM, ASCENSÃO L \& DEMARCO D. 2016. Foliar colleters in Anacardiaceae: first report for the family. Botany 94: 337-346. 
LIN S \& BERNARDELLO G. 1999. Flower structure and reproductive biology in Aspidosperma quebracho-blanco (Apocynaceae), a tree pollinated by deceit. International Journal of Plant Science 160: 869-878.

MARCONDES-FERREIRA W. 1999. A new species of Aspidosperma Mart. (Apocynaceae) from Bahia, Brazil. Brittonia 51: 74-76.

MARTINS FM, KINOSHITA LS \& CASTRO MM. 2010. Coléteres foliares e calicinais de Temnadenia violacea (Apocynaceae, Apocynoideae): estrutura e distribuição. Revista Brasileira de Botânica 33: 489-500.

MARTINS FM, LIMA JF, MASCARENHAS AAS \& MACEDO TP. 2012. Secretory structures of Ipomoea asarifolia: anatomy and histochemistry. Revista Brasileira de Farmacognosia 22: 13-20.

MARTINS FM, MASCARENHAS AAS, MACEDO TP \& CUNHA NETO IL. 2013. Estruturas secretoras em órgãos vegetativos e florais de Secondatia densiflora A.DC. (Apocynaceae - Odontadenieae). Revista Brasileira de Plantas Medicinais de Botucatu 15: 13-24.

MOHAN JSS \& INAMDAR JA. 1986. Ultrastructure and secretion of extrafloral nectaries of Plumeria rubra L. Annals of Botany 57: 389-401.

RAMAYYA N \& BAHADUR B. 1968. Morphology of the "squamellae" in the light of their ontogeny. Current Science 18: 520-522.

RAO VS \& GANGULI A. 1963. Studies in the floral anatomy of the Apocynaceae. Journal of the Indian Botanical Society 42: 419-435. 
RIBEIRO JC, FERREIRA MJP \& DEMARCO D. 2017. Colleters in Asclepiadoideae (Apocynaceae): protection of meristems against desiccation and new functions assigned. International Journal of Plant Sciences 178: 465-477.

RIO MCS do. 2006. Estudos anatômicos em espécies de Forsteronia G.Mey. (Apocynaceae) de cerrado. Campinas, Tese de Doutorado, Instituto de Biologia, Universidade Estadual de Campinas.

RIO MCS do, CASTRO M de M \& KINOSHITA LS. 2002. Distribuição e caracterização anatômica dos coléteres foliares de Prestonia coalita (Vell.) Woodson (Apocynaceae). Revista Brasileira de Botânica 25: 339-349.

RIO MCS do \& KINOSHITA LS. 2005. Prestonia (Apocynaceae) no sul e sudeste do Brasil. Hoehnea 32: 233-258.

SENNBLAD B, ENDRESS ME \& BREMER B. 1998. Morphology and molecular data in phylogenetic fraternity: the tribe Wrightieae (Apocynaceae) revisited. American Journal of Botany 85: 1143-1158.

SIMÕES AO, CASTRO M de M \& KINOSHITA LS. 2006. Calycine colleters of seven species of Apocynaceae (Apocynoideae) from Brazil. Botanical Journal of the Linnean Society 152: $387-398$.

SIMÕES AO, ENDRESS ME \& CONTI E. 2010. Systematics and character evolution of Tabernaemontaneae (Apocynaceae, Rauvolfioideae) based on molecular and morphological evidence. Taxon, 59: 772-790. 
SIMÕES AO, RIO MCS do, CASTRO M de M \& KINOSHITA LS. 2007. Gynostegium morphology of Mesechiteae Miers (Apocynaceae, Apocynoideae) as it pertains to the classification of the tribe. International Journal of Plant Sciences 168: 999-1012.

SIMPSON MG. 2006. Plant systematics, 1st edn. Boston: Elsevier - Academic Press.

SOLEREDER H. 1908. Systematic anatomy of the dicotyledons. English translation by L.A. Boodle and F.E. Fritsch, Clarendon Press, Oxford.

SOUZA VC \& LORENZI H. 2005. Botânica sistemática. Nova Odessa, Instituto Plantarum, 703p.

SUBRAMANIAN RB, MURUGAN V, MOHAN JSS \& INAMDAR JA. 1989. Optical microscopic studies on the structure and secretion of resin glands in some Apocynaceae. Proceedings of Indian Academy Sciences (Plant Sciences) 99: 423-429.

THOMAS V. 1991. Structural, functional and phylogenetic aspects of the colleter. Annals of Botany 68: 287-305.

THOMAS V \& DAVE, Y. 1989a. The colleters of Alstonia scholaris L. (Apocynaceae). Indian Botanical Contactor 6: 25-29.

THOMAS V \& DAVE Y. 1989b. Structure, origin, development and senescence of colleters in Nerium indicum Mill. ( $N$. odorum Soland., Apocynaceae). Korean Journal of Botany 32: 163-172. 
THOMAS V \& DAVE Y. 1991. Comparative and phylogenetic significance of colleters in Apocynaceae. Feddes Repertorium 102: 23-28.

THOMAS V, DAVE Y \& MENON ARS. 1989. Anatomy and histochemistry of colleters in Roupelia grata Wall. (Apocynaceae). Nordic Journal of Botany 8: 493-496.

TORRES C \& GALETTO L. 1998. Patterns and implications of floral nectar secretion, chemical composition, removal effects and standing crop in Mandevilla pentlandiana (Apocynaceae). Botanical Journal of the Linnean Society $127:$ 207-223.

VIEIRA MF \& SHEPHERD GJ. 2002. Oxypetalum banksii subsp. banksii. a taxon of Asclepiadaceae with an extragynoecial compitum. Plant Systematics and Evolution 233: 199-206.

VOGEL S. 1990 The role of scent glands in pollination. On the structure and function of osmophores. New Delhi, Amerind Publishing.

WOODSON RE Jr \& MOORE JA. 1938. The vascular anatomy and comparative morphology of Apocynaceae flowers. Bulletin of the Torrey Botanical Club 65:135-165. 


\section{SECRETORY PATTERNS IN COLLETERS OF}

\section{APOCYNACEAE}

Josiana Cristina Ribeiro and Diego Demarco

Departmento de Botânica, Instituto de Biociências, Universidade de São Paulo, 05366-100, São Paulo, Brazil 


\section{INTRODUCTION}

The secretion of the colleters is viscous and may consist of mucilage, resin (Thomas 1991) or a mixture of mucilage and lipophilic substances (Fahn 1979a, 1990, Castro \& Demarco 2008). Histochemical studies have demonstrated that the colleters of Apocynaceae are found in the shoot apex and floral calyces and secrete mainly mucilage and lipids, which involves the meristems and developing organs, protecting them against desiccation, fungi and/or small phytophagous insects (Ribeiro et al. 2017). The complete production of the colleter secretion occurs in the epidermal cells. These secretory cells have a dense cytoplasm with a heterogeneous aspect and many vacuoles of various sizes with lipophilic content (Demarco 2008).

The secretion of the colleters is accumulated in a periplasmic space before being released to outside through the wall and the cuticle, without breaking it (Rio et al. 2002, Demarco 2005, 2008, Marasca 2008, Canaveze \& Machado 2015). However, the release of secretion through rupture of the cuticle has already been reported to the family (Fjell 1983, Kuriachen \& Dave 1989, Fahn 1990, Schwarz \& Furlan 2002) and there are reports of separation of cells due to dissolution of the middle lamella related to secretion release (Mohan \& Inamdar 1986, Thomas \& Dave 1989a, Appezzato-da-Glória \& Estelita 2000). In Tabernaemontana catharinensis, evidence of eccrine and granulocrine secretion types was observed (Canaveze \& Machado 2015), reinforcing the 
need for further studies with the group to verify the various aspects of the secretory process in other species.

Considering that some species have colleters whose secretion is heterogeneous, composed of mucilage and lipophilic substances, and others have exclusively mucilaginous secretion (Ribeiro et al. 2017), an analysis of the secretory mechanism of the different colleters is relevant to understand the evolution of the gland in this group. Due to the lack of ultrastructural studies in the family demonstrating the production mode of the secretion and its release to the outside, we aim to describe the secretory cells of colleters in four species of Apocynaceae with different secretion composition. We have also performed the first comparative analysis of the subcellular secretory mechanisms in relation to the secretion metabolites in colleters.

\section{Material and methods}

The individuals were collected in São Paulo/SP and in the Parque Estadual da Serra do Mar in Ubatuba/SP. Voucher was provided for each species through the collection of reproductive branches and the deposit of exsiccates in the Herbarium SPF (USP).

The species chosen for the present study were selected based on the type of secretion produced, according to a previous histochemical study (Ribeiro et al. 2017) and personal observation, namely: 
- Allamanda schottii Pohl (Rauvolfioideae) - production of a heterogeneous secretion.

- $\quad$ Blepharodon bicuspidatum E.Fourn. (Asclepiadoideae) - production of a heterogeneous secretion.

- Mandevilla splendens (Hook.f.) Woodson (Apocynoideae) - production of a mucilaginous secretion.

- $\quad$ Peplonia axillaris (Vell.) Fontella \& E.A.Schwarz. (Asclepiadoideae) production of a mucilaginous secretion.

\section{Scanning electron microscopy}

For the micromorphological study, shoot apices were fixed in FAA (formalin, acetic acid and ethyl alcohol) for 24 h (Johansen 1940), isolated, dehydrated in ethanol series, dried by the critical point method, mounted on aluminum stub and covered with gold, with subsequent observation in a Jeol JSM 5800 LV scanning electron microscope.

\section{Light microscopy}

For the anatomical analysis, shoot apices and the subsequent nodes were isolated, fixed in BNF (buffered neutral formalin) in $0.1 \mathrm{M}$ sodium phosphate buffer, pH 7.0 (Lillie 1965) for 48h, dehydrated in a butyl series (tertiary butyl alcohol; Johansen 1940), embedded in Paraplast (Leica Microsystems Inc., Heidelberg, Germany) and sectioned transversely and longitudinally in a Leica RM2145 rotary microtome. The thickness of the sections ranged from 10 to $12 \mu \mathrm{m}$. The sections were stained with astra blue 
and safranin (Gerlach 1984) and the slides mounted in synthetic resin. The observations and the photographic records were performed under a Leica DMLB light microscope (Leica Microsystems Inc., Heidelberg, Germany).

\section{Transmission electron microscopy}

For the ultrastructural study, shoot apices were isolated and fixed in 2.5 $\%$ glutaraldehyde in $0.1 \mathrm{M}$ sodium phosphate buffer, $\mathrm{pH} 7.2$, postfixed in $1 \%$ osmium tetroxide, dehydrated in a graded ketone series and included in Spurr resin. The sectioning was performed in a Leica Ultracut UCT (Leica Microsystems Inc., Heidelberg, Germany) and the ultrathin sections were stained with uranyl acetate (Watson 1958) and lead citrate (Reynolds 1963) with subsequent observation in a Zeiss EM900 transmission electron microscope.

For the analysis of the secretory activity, cytochemical tests were performed using ruthenium red for detection of acidic carbohydrates (Luft 1971), imidazole-buffered osmium tetroxide for lipids (Angermüller \& Fahimi 1982) and PATAg (periodic acid, thiosemicarbazide and silver proteinate; Thiéry 1967) for polysaccharides, facilitating the observation of the interaction between the organelles of the endomembrane system. 


\section{Results}

In all the analyzed species, the foliar colleters have similar morphology and anatomy, standing out the absence of vasculature, and vary only in relation to the presence or absence of stalk.

\section{Distribution}

Colleters are located in the shoot apices and are easily observable to the naked eye in the nodal regions, occupying petiolar and interpetiolar positions. The interpetiolar ones occur on the sides of the petioles in Allamanda (Fig. 1a, b), and they are distributed continuously between the petioles in Blepharodon, Mandevilla and Peplonia (Fig. 1c-f). The petiolar colleters are located at the base of the petioles, near the leaf axile in Allamanda (Fig. 1a-b) and Mandevilla, or in the distal portion of the petiole near the leaf blade in Blepharodon (Fig. 1d) and Peplonia.

\section{Morphology}

Foliar colleters are conical, entire, rarely bifid and deciduous. They have a broad base in Allamanda (Fig. 1a, b) and in Peplonia (Fig. 1f) and are rectilinear in Blepharodon and Mandevilla (Fig 1c-e). Morphologically the colleters can be of two types, stalked and sessile. Allamanda (Fig. 2a), Blepharodon (Fig. 2c) and Mandevilla (Fig. 1e) have stalked colleters, and Peplonia has sessile ones (Fig. 2e). 


\section{Anatomy}

Anatomically, the stalked colleters present a non-secretory basal portion while the sessile ones are completely coated by a secretory epidermis. In all species, the secretory portion of the colleters present a non-secretory parenchymatic axis devoid of vascularization formed by cells elongated longitudinally in relation to the colleter and covered by a secretory epidermis uniseriate, composed by rectangular cells in palisade (Fig. 2d-f). Epidermal cells have fine walls and cuticle, dense cytoplasm (Fig. 2b, f, g) and vacuoles of various sizes (Fig. $2 g, h$ ). Cells in the early stage of the secretory process have vacuoles occupying the basal portion of the cells (Fig. $2 \mathrm{~g}$ ). And those in the final phase of the secretion present one large central vacuole occupying most of cell lumen, as well nucleus with a conspicuous nucleolus (Fig. 2h). The colleters secrete a viscous white exudate, which permeates whole the shoot apex (Fig. 1b, 2a, b). No fungal proliferation was observed in Allamanda and Blepharodon but a large amount of fungi was recorded in Peplonia (Fig. 1f, 2i). All the colleters of the same species produce the same type of secretion during the entire secretory activity.

\section{Ultrastructure}

Colleters with mucilaginous secretion (Mandevilla splendens and Peplonia axillaris) 


\section{Cell wall}

The secretory cells have fine walls and cuticle (Fig. 3a), being observed a great amount of pectin projections of the outer periclinal wall through the cuticle (Fig. 3b). The anticlinal walls present a large amount of plasmodesmata, facilitating the exchange of material between the secretory cells (Fig. 3c).

\section{Cytoplasm}

Epidermal cells have a dense cytoplasm rich in ribosomes with an extensive network of rough endoplasmic reticulum (RER) (Fig. 3d), a profusion of hyperactive dictiosomes (Fig. 3d-e), large mitochondria, vacuoles and many scattered vesicles (Fig. 3a, d-j). Plastids were rarely found (Fig. 3f). Large amount of mucilage within the vacuole and vesicles was recorded (Fig. 3e, g-j). The abundance of vesicles filled with secretion on the trans face of the dictiosomes indicates a large production of mucilage (Fig. 3i) which is transferred to the RER, which is mainly associated with the dictiosomes in a peripheral position, near the plasma membrane in the distal portion of the cell

(Fig. 3d, j). The secretion produced in the proximal (basal) portion of the cell is temporarily stored in the vacuole (Fig. 3a).

\section{Secretion release}

The release mechanism is granulocrine. Fusion of vesicles and small vacuoles with the plasma membrane is observed in the apical region of the cell, releasing the secretion outside the protoplast both near the periclinal cell wall and the distal portion of the anticlinal wall (Fig. 4a, b). After the fusion of the 
vesicles with the plasma membrane, the secretion is transferred to a large periplasmic space before crossing the cell wall and the cuticle (Fig. 4a) or before moving to the adjacent cell (Fig. 4b-d). During the passage of the secretion through the outer periclinal wall, also occurs the formation of a cavity within the cell wall, here named intramural space (Fig. 4e, f). Thus, there are two sites of temporary extraprotoplastic accumulation of the secretion before its release to the surface of the gland: one periplasmic and other intramural. After completely crossing the wall, the secretion passes through the projections of pectin in the cuticle, being released to outside without breaking it.

Colleters with heterogeneous secretion (Allamanda schottii and Blepharodon bicuspidatum)

Cell wall

The walls of the secretory cells are usually thin, covered by a fine cuticle (Fig. 5a) that has many projections of pectin crossing all its extension (Fig. 5b). Plasmodesmata were not observed between the epidermal cells.

Cytoplasm

The species present a dense cytoplasm rich in ribosomes. The RER is prominent and is preferably located in parietal position (Fig. 5c-d), dictiosomes were also seen close to the membrane (Fig. 5e). There are many plastids with plastoglobules and starch grains (Fig. 5a, f) and mitochondria (Fig 5a, f). Vacuoles and vesicles of various sizes with fibrillar osmiophilic material and granular material occupy most of the protoplast (Fig. 5a, c, g-i). Large number 
of vesicles containing mucilage and oil bodies was evidenced in Blepharodon species (Fig. 5h). After production of mucilage from dictiosomes, the vesicles are directly transported to the distal portion of the cell to be released (Fig. 5h) or may be temporarily stored inside the vacuole (Fig. $5 \mathrm{~g}$ ) when produced in the proximal portion of the cell. In the same way, oil bodies found free in the cytosol (Fig. 5h) are produced in the plastids and may be directly released or temporarily stored in the vacule (Fig. $5 \mathrm{~g}$ ). Allamanda secretes a much larger amount of lipids (Fig. 5i) than Blepharodon.

\section{Release mode}

The release mechanism is mainly granulocrine. Several vesicles and small vacuoles containing secretion derive from dictiosomes, RER and also from the central vacuole and move towards the plasma membrane in the distal portion of the cell (Fig. 6 a-d). Vesicles originated from dictiosomes are directed to the RER where proteins are added, and then vesicles formed by the RER are released to fuse with the plasma membrane (Fig. 6e). A large amount of heterogeneous secretion, containing mucilage and lipids, is transferred to a reduced, restricted periplasmic space near the outer periclinal wall. Then the secretion rapidly crosses the cell wall, being temporarily accumulated in a large subcuticular space (Fig. 6f). Partly, the oil bodies may freely cross the plasma membrane in an eccrine release mode, being posteriorly accumulated in the subcuticular space. Despite the large amount of secretion underneath the 
cuticle, pushing it, no rupture was observed during secretion pathway to outside. 
Figure 1. Morphology of colleters in Allamanda schottii (a, b), Blepharodon bicuspidatum (c, d), Mandevilla splendens (e), Peplonia axillaris (f). Scanning electron microscopy. [White arrows $=$ interpetiolar colleters; black arrow $=$ colleter stal; arrowheads $=$ petiolar colleters; asterisk $=$ fungi; $\mathrm{S}=$ secretion $]$. 


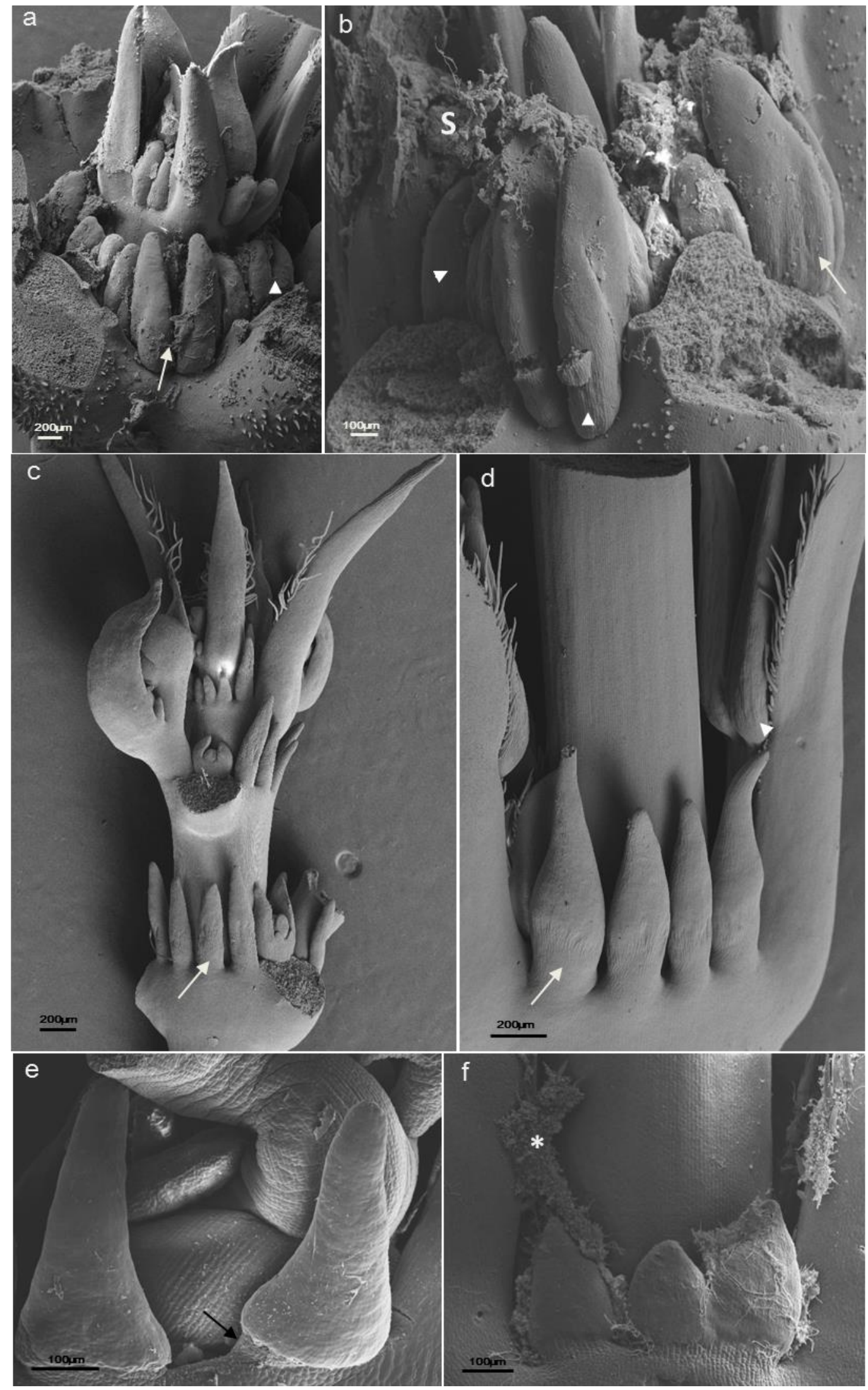


Figure 2. Anatomy of colleters in Allamanda shottii (a, b), Blepharodon bicuspidatum (c, d, g, h), Peplonia axillaris (e, f, i). Longitudinal sections. (a, c, $e, h)$ General view. (b, $d, f, g, i)$ Detail of the secretory epidermis covering a parenchymatic core. Note the presence of small vacuoles in the secretory cells (arrows) and the absence of vasculature. (i) Fungal hyphae (asterisk) on the mucilaginous colleter. [S = secretion]. 


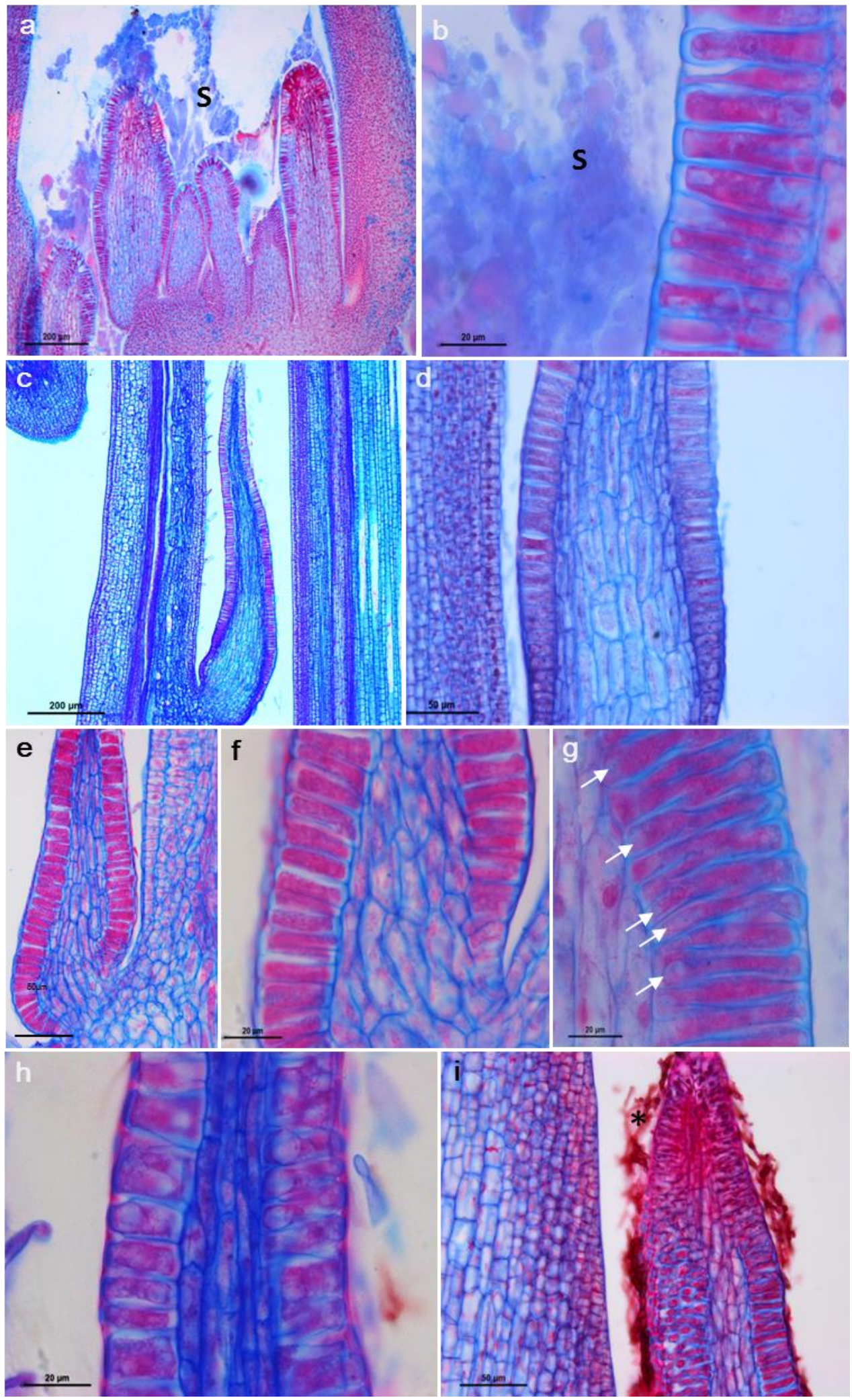


Figure 3. Ultrastructure of the secretory cells of colleters in Mandevilla splendens (a-h, j) and Peplonia axillaris (i). (a) General view. (b) Cuticle with pectin projections. (c) Detail of a plasmodesma. (d) Abundant dictiosomes (arrowhead) and rough endoplasmic reticulum (RER) in parietal position. (e, g-j) Vesicles filled with mucilage (asterisk). (f) Plastid with plastoglobules (P) surrounded by many mitochondria $(M)$. $(g, h)$ Detection of polysaccharides within vesicles with PATAg test. (i) Detection of mucilage in the vesicles of the trans-Golgi network using ruthenium red test. (j) Beginning of a vesicle formation from RER near plasma membrane. 

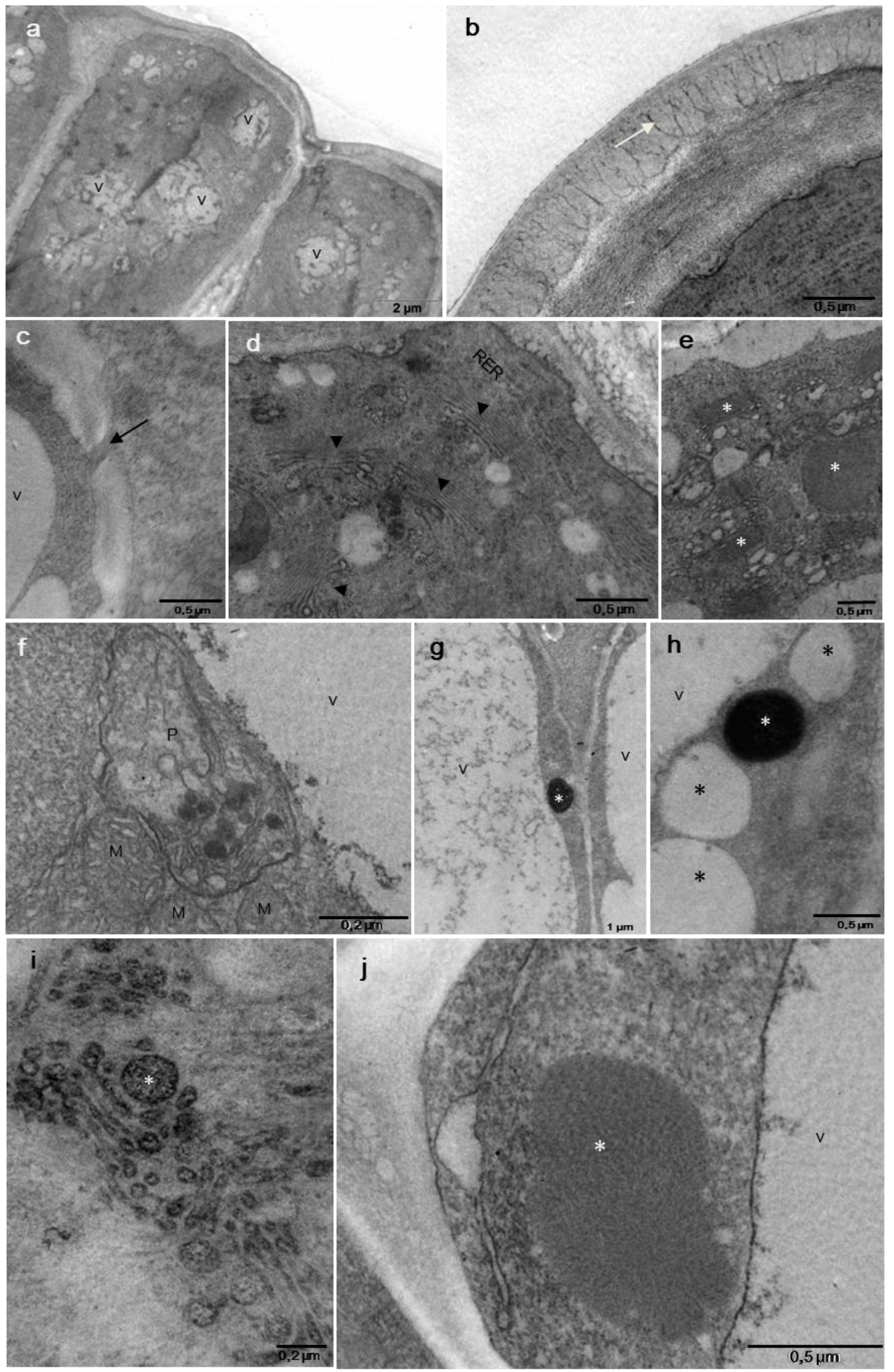
Figure 4. Secretion release in colleters of Peplonia axillaris (a, b) and Mandevilla splendens (c-f). (a-d) Fusion of vesicles with plasma membrane and formation of a large periplasmic space. (e, f) Intramural space filled with secretion. [asterisk = periplasmic space with secretion; arrow = vesicle; $\mathrm{PL}=$ pectin-rich layer; $\mathrm{S}=$ secretion]. 


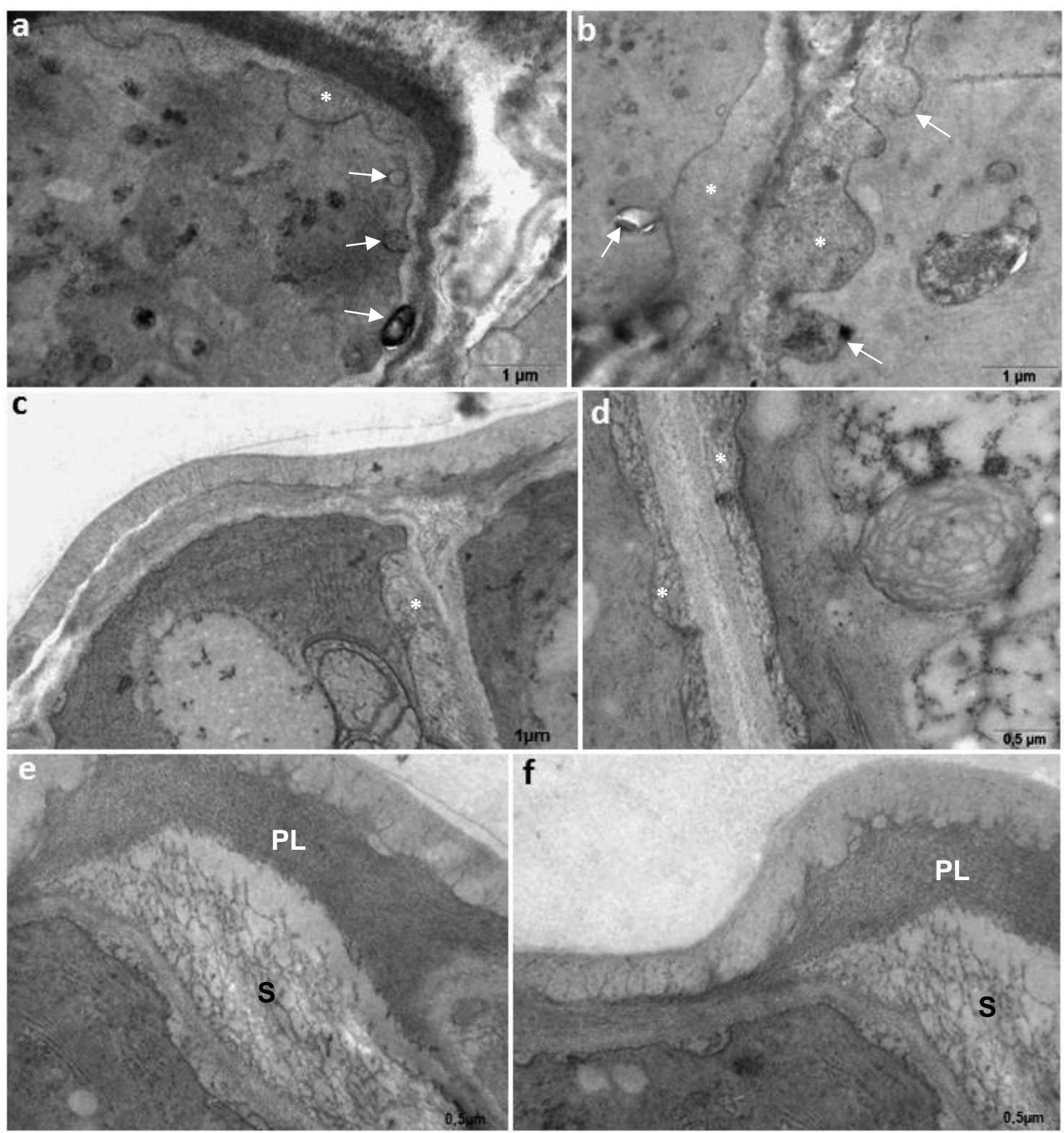


Figura 5. Ultrastructure of the secretory cells of colleters in Blepharodon bicuspidatum (a-b, d-f, h) and Allamanda shottii (c, g, i). (a, c) Vacuoles with heterogenous content. (b) Pectin projections into the cuticle. (d) Vesicle formed by RER fusing with the tonoplast. (e) Dictiosome vesicles being directed to the plasma membrane. (f) Plastids with starch grains and mitochondria. (g) Large central vacuole filled with secretion. (h) Vesicles with polysaccharides detected using PATAg test (asterisk) and oil bodies (OB). (i) Detection of lipids with imidazole-osmium tetroxide test in the secretion on the colleter. [Arrow $=$ pectin projections within cuticle; arrowhead $=$ dictiosome; $\mathrm{M}=$ mitochondrion; $\mathrm{P}=$ plastid; RER = rough endoplasmic reticulum; $\mathrm{V}=$ vacuole] 


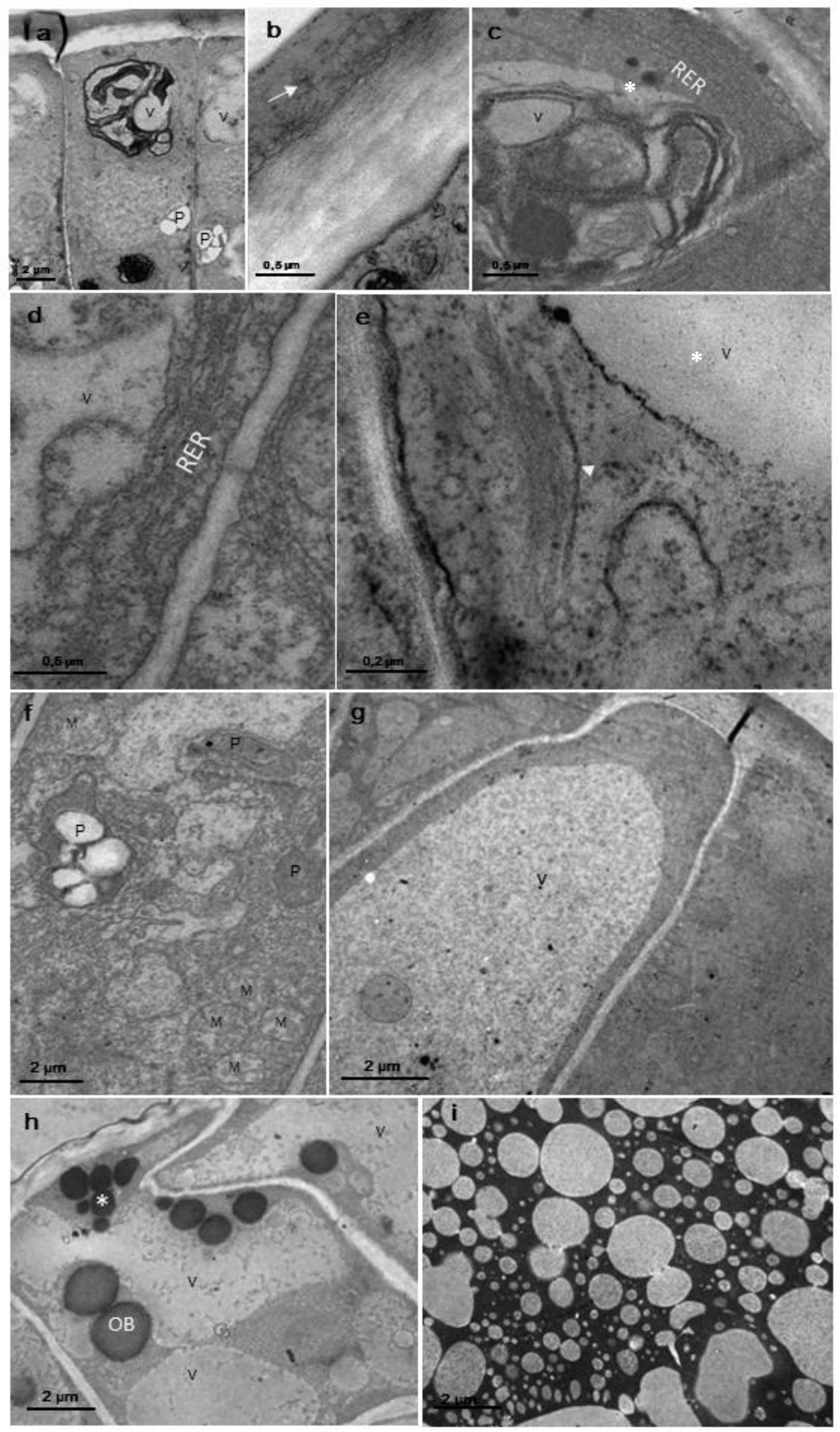


Figure 6. Secretion release in colleters of Allamanda shottii (a-b, e-f) and Blepharodon bicuspidatum (c-d). (a, e) Vesicles newly fused with plasma membrane transferring the secretion to the periplasmic space. (b) Small vacuole with heterogenous secretion. (c, d) PATAg test evidencing polysaccharides in vesicles (asterisk). Note plastid $(P)$ with starch grains and plastoglobules, and mitochondria (M). (f) Presence of heterogenous secretion in the subcuticular space. [S = secretion; $V=$ vacuole]. 


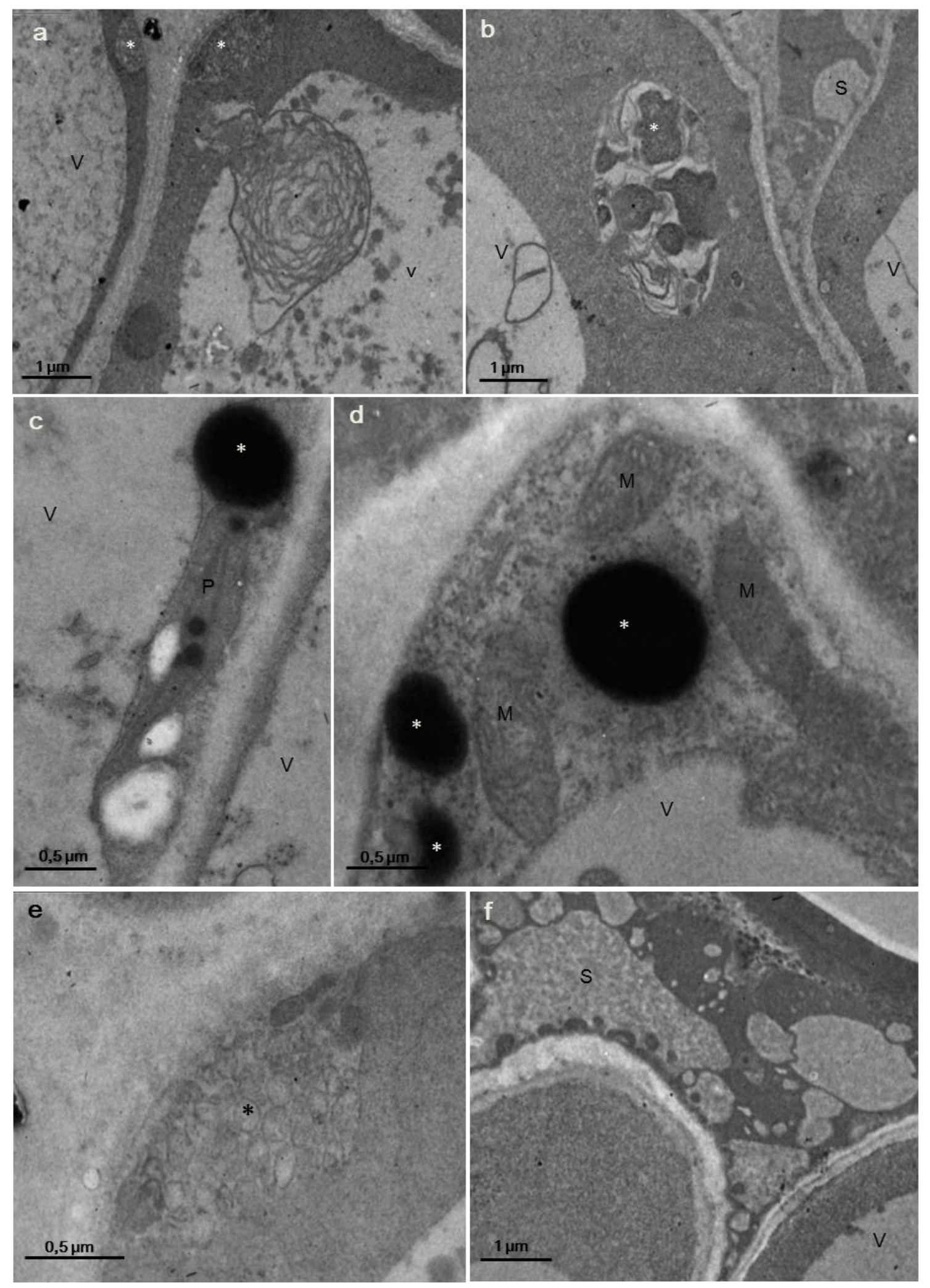




\section{Discussion}

Foliar colleters were found in petiolar and interpetiolar regions of the shoot apex, producing the same type of secretion during the entire period of the secretory activity, and two patterns of secretory process and mode of release were described, according to the secretion composition.

In Apocynaceae, foliar colleters may be present in the margin of the leaf blade, petioles, bracts, bracteoles and cotyledons (Thomas 1991; Sennblad et al. 1998; Appezzato-da-Glória \& Estelita 2000; Canaveze \& Machado 2015). The colleters studied here can be described as standard type, as well as in most Apocynaceae (Thomas 1991; Canaveze \& Machado 2015; Demarco 2017a). Only one layer of secretory epidermal cells are observed in these colleters (Thomas 1991, Appezzato-da-Glória \& Estelita 2000, Rio et al. 2002, Martins et al. 2010, Martins et al. 2013, Canaveze \& Machado 2015; Demarco 2017a), which characteristically have thin walls and large vacuoles. However, Tabernaemontana has cells with poorly developed vacuoles, and the periclinal walls are thicker than the anticlinal ones (Canaveze \& Machado 2015). This differential thickness may be related to the mode of secretion release. Miguel et al. (2017) observed that the structural organization of the outer periclinal cell wall of colleters in Bathysa changes during secretion passage, which happens mainly due to accumulation of secretion within the wall. These authors also classified this region of the cell wall as a dynamic structure with an active role in the release of secretion via constant structural reorganization. 


\section{Secretory machinery}

Mucilaginous secretion - Mandevilla and Peplonia

Colleters of Mandevilla and Peplonia secrete mucilage and proteins (Ribeiro et al. 2017). The predominant organelles observed in the secretory cells are dictiosomes, which produce the mucilaginous secretion that is transferred to the rough endoplasmic reticulum through vesicles. In the RER, proteins are added to the secretion, and vesicles derived from the RER are transported to the plasma membrane, where the secretion is released to the periplasmic space, or to the vacuole, where the secretion is temporarily stored. Mucilage is the main component of the colleter secretion in Apocynaceae (Demarco 2017a) and was detected in foliar colleters of several genera of the family, as Allamanda, Asclepias, Blepharodon, Chloropetalum, Fischeria, Forsteronia, Oxypetalum, Peplonia, Plumeria, Prestonia, Rauvolfia, Roupelia and Tabernaemontana (Mohan \& Inamdar 1986, Thomas \& Dave 1989a, Thomas et al. 1989; Appezzato-da-Glória \& Estelita 2000; Rio 2001, 2006; Rio et al. 2002; Marasca 2008; Canaveze \& Machado 2015; Ribeiro et al. 2017). Proteins have also been recorded in the secretion of colleters in Plumeria (Mohan \& Inamdar 1986), Allamanda, Alstonia (Thomas \& Dave 1989a,b), Roupelia (Thomas et al. 1989) and genera of the subfamily Asclepiadoideae (Ribeiro et al. 2017).

The close association between rough endoplasmic reticulum and dictiosomes producing vesicles near the plasma membrane has been noticed in 
colleters of other genera, such as Bathysa (Miguel et al. 2006) and Tabernaemontana (Canaveze \& Machado 2015). The abundant presence of vesicles in the epidermis indicates a constant production of exudate, since they were also recorded for Tabernaemontana (Canaveze \& Machado 2015) and in colleters of other families (Paiva \& Machado 2006).

Organelles related to the synthesis of lipophilic compounds were rare or not observed in Mandevilla and Peplonia. Few plastids occur in the secretory cells, and osmiophilic compounds were restrited to the plastoglobules. Smooth endoplasmic reticulum was not observed, and the imidazole-osmium tetroxide test has not detected the presence of lipids in the secretion. However, SER is present in colleters of Bathysa (Miguel et al. 2010), which secrete a heterogeneous exudate.

Heterogeneous secretion - Allamanda and Blepharodon

Colleters of Allamanda and Blepharodon produce mucilage, proteins, lipids and phenolic compounds (Castro \& Demarco 2008; Ribeiro et al. 2017). The synthesis of mucilage and proteins is made in a similar way to that of Mandevilla and Peplonia. However, those colleters distinguish from the mucilaginous ones in relation to the vacuome composed of one large vacuole or many vacuoles of various sizes containing a heterogeneous secretion, in addition to abundant plastids containing starch and plastoglobules. Since SER was not observed in both genera, plastids should be the responsible for the production of lipids in the colleters. Plastids containing starch were also 
detected inside the secretory cells in Plumeria (Mohan \& Inamdar 1986), Allamanda (Thomas \& Dave 1989a) and Mandevilla (Appezzato-da-Glória \& Estelita 2000) and in parenchyma cells of Alstonia (Thomas \& Dave 1989b) and Tabernaemontana (Canaveze \& Machado 2015). The presence of starch within the plastids serves to produce nutritional and energy reserve for the production of secretion by epidermal cells (Demarco 2005).

\section{Secretion release}

The mode of secretion release from the protoplast is granulocrine for all species but the way it cross the cell wall and cuticle differ between colleters with mucilaginous secretion and those with heterogenous secretion. The granulocrine release occurs in a similar way in all colleters, independently of the secretion type. Vesicles and small vacuoles fuse to plasma membrane in the distal portion of the cell, transferring their content to the periplasmic space. In the mucilagionous colleters, this space is large and the cell wall represents the first barrier to the exudation of the secretion to outside.

According to Paiva (2016), viscous secretions as mucilage cannot cross passively the cell wall and need to be actively pushed by the protoplast. Although the periplasmic space is not as wide as predicted by the cell cycle proposed by Paiva (2016), the need of an action of the protoplast pressing the mucilage to cross the wall is evident. During the crossing of the secretion within the wall, a second space is formed in the colleters of Mandevilla and Peplonia, where the mucilage is temporarily accumulated. This intramural space is formed 
due to the rupture of the outer periclinal wall in its distal part, which is a pectinrich region beneath the cuticle. Afterward, the mucilage crosses the cuticle through cell wall pectin projections without any damage, reaching the colleter surface.

Despite the presence of lipids and probable higher viscosity of the secretion in colleters of Allamanda and Blepharodon, the granulocrine process produces small periplasmic spaces, relative to the area of vesicle fusion, which rapidly disappear with the passage of the secretion through the wall without resistance apparently. This difference may indicate a distinct pectin composition of this region of the cell wall, since pectins are the main responsible for the porosity of the cell wall. However, more studies are needed to verify this hypothesis. Although this heterogenous secretion can pass through the wall, it causes the detachment of the cuticle, being accumulated in a large subcutilar space. The increasing pressure in this space due to the constant addition of more secretion probably is the responsible for pressing the exudate to cross the cuticle, reaching the colleter surface. This action does not rupture the cuticle. According to Paiva (2017), the secretion passes through micropores or microchannels within the cuticle.

The release of secretion mediated by vesicles or vacuoles is the main mechanism of exudation observed in colleters. Secretory vesicles which migrate and fuse with plasma membrane releasing the secretion in the periplasmic space occur also in Copaifera (Fabaceae), Tabernaemontana and Bathysa 
(Paiva 2009; Miguel et al. 2010; Canaveze \& Machado 2015). Secretory cells release the secretion to outside via granulocrine secretion, and this is also the main mechanism of secretion transference cell-to-cell, although part of the mucilaginous secretion may be transferred through plasmodesmata in Mandevilla and Peplonia. However, at least partly, some lipids may be directly released through plasma membrane without to be package in vesicles (eccrine release) in Allamanda and Blepharodon. Despite this novel description for colleters, the granulocrine release is the main secretory mechanism reported to colleters.

According to Fahn (1979b), the release of secretion to outside may occur due to the gradient concentration or by active process. Most colleters of Apocynaceae exude without rupture the cuticle (Rio et al. 2002; Marasca 2008; Demarco 2017a). The passage of a hydrophilic substance through a hydrophobic substance (cutin) without breaking the cuticle can be explained by the presence of pectin projections of the cell wall through the cuticle, due to the hydrophilic character of the pectin (Gama et al. 2016). However, the release of secretion through rupture of the cuticle was reported in previous studies (Fjell 1983, Kuriachen \& Dave 1989, Fahn 1990, Schwarz \& Furlan 2002).

After the secretion is released to the surface, it involves whole shoot apex and has the function of protecting the meristems (Thomas 1991). This protection may be against desiccation due to the hygroscopic character of the mucilage (Fahn 1979a, Simões et al. 2004; Ribeiro et al. 2017) and against 
small phytophagous insects, immobilizing them (Ribeiro et al. 2017). In addition, lipids produced by secretory cells are responsible for inhibiting the proliferation of fungi in the meristematic regions, which occur due to the presence of mucilage, since the proliferation of hyphae over the entire shoot apex is significant in Peplonia, a genus with mucilaginous colleter (Ribeiro et al. 2017).

Our study found two patterns of colleter exudation related to the composition of secretion. The mechanisms described here unveil a diversity of secretory processes in a group with apparently homogenous colleter morphology and anatomy, raising new questions for future studies, specially in relation to the composition of the outer periclinal wall, and why the passage of secretion through the wall and cuticle eventually forms intramural or subcuticular spaces. 


\section{Literature cited}

ANGERMÜLLER S \& FAHIMI DH. 1982. Imidazole-buffered osmium tetroxide: na excelente stain for visualization of lipids in transmission electron microscopy. Histochemical Journal 14: 823-825.

APPEZZATO-DA-GLÓRIA B \& ESTELITA MEM. 2000. Development, structure and distribution of colleters in Mandevilla illustris and $M$. velutina (Apocynaceae). Revista Brasileira de Botânica 23: 113-120.

BARREIRO DP \& MACHADO SR. 2007. Coléteres dendróides em Alibertia sessilis (Vell.) K. Schum., uma espécie não-nodulada de Rubiaceae. Revista Brasileira de Botânica 30: 387-399.

CANAVEZE Y \& MACHADO SR. 2015. Leaf colleters in Tabernaemontana catharinensis (Apocynaceae, Rauvolfioideae): structure, ontogenesis, and cellular secretion. Botany 93: 287-296.

CASTRO M de M \& DEMARCO D. 2008. Phenolic compounds produced by secretory structures in plants: a brief review. Natural Product Communications 3: 1273-1284.

DEMARCO D. 2005. Estruturas secretoras florais e coléteres foliares em espécies de cerrado de Aspidosperma Mart. E Blepharodon Decne. (Apocynaceae s.l.). Campinas, Master Thesis, Instituto de Biologia, Universidade Estadual de Campinas. 
DEMARCO D. 2008. Glândulas de órgãos vegetativos aéreos e florais de espécies de Asclepiadeae (R.Br.) Duby (Asclepiadoideae, Apocynaceae) de Mata Atlântica do Estado de São Paulo. Campinas, PhD Thesis, Instituto de Biologia, Universidade Estadual de Campinas.

FAHN A. 1979a. Secretory tissues in plants. London, Academic Press.

FAHN A. 1979b. Ultrastructure of nectaries in relation to nectar secretion. Am J Bot 66(8): 977-985.

FAHN A. 1990. Plant anatomy. 4th ed., Oxford, Pergamon Press.

FJELL I. 1983. Anatomy of the xeromorphic leaves of Allamanda nerifolia, Thevetia peruviana and Vinca minor (Apocynaceae). Nordic Journal of Botany 3: 383-392.

GAMA TSS, AGUIAR-DIAS ACA \& DEMARCO, D. 2016. Transfer cells in trichomatous néctar in Adenocalymma magnificum (Bignoniaceae). Anais da Academia Brasileira de Ciências. 88: 527-237.

GERLACH D. 1984. Botanische mikrotechnik: eine einfu"hrung, 3rd edn. Stuttgart: Georg Thieme.

JOHANSEN DA. 1940. Plant microtechnique. New York: McGraw-Hill.

KURIACHEN PM \& DAVE Y. 1989. Structural, developmental and histochemical studies in the colleters of Calotropis L. (Asclepiadaceae). Journal of Phytological Research 2: 7-14.

LILLIE RD. 1965. Histopathologic Technic and Pratical Histochemistry, 3rd edn. New York: McGraw-Hill. 
LUFT JH. 1971. Ruthenium red and violet. II. Fine structural localization in animal tissues. Anatomical Record 171: 369-415.

MARASCA RM. 2008. Estruturas secretoras em Rauvolfia sellowii Müll.Arg. (Apocynaceae, Rauvolfioideae, Vinceae). Campinas, Tese de mestrado, Instituto de Biologia, Universidade Estadual de Campinas.

MARTINS MF, KINOSHITA LS \& CASTRO MM. 2010. Coléteres foliares e calicinais de Temnadenia violácea (Apocynaceae, Apocynoideae): estrutura e distribuição. Revista Brasileira de Botânica 33: 489-500.

MARTINS FM, MASCARENHAS AAS, MACEDO TP \& CUNHA NETO IL. 2013. Estruturas secretoras em órgãos vegetativos e florais de Secondatia densiflora A.DC. (Apocynaceae - Odontadenieae). Revista Brasileira de Plantas Medicinais de Botucatu 15: 13-24.

MERCADANTE-SIMÕES MO \& PAIVA EAS. 2013. Leaf colleters in Tontelea micrantha (Celastraceae, Salacioideae): Ecological, morphological and structural aspects. Comptes Rendus Biologies, 336: 400-406.

MIGUEL EC, GOMES MV, OLIVEIRA MA \& CUNHA M. 2006. Colleters in Bathysa nicholsonii K. Schum. (Rubiaceae): Ultrastructure, secretion protein composition, and antifugal activity. Plant Biol. 8: 715-722.

MIGUEL EC, KLEIN DE, OLIVEIRA MA \& CUNHA, M. 2010. Ultrastructure of secretory and senescence phase in colleters of Bathysa gymnocarpa and $B$. stipulate (Rubiaceae). Revista Brasileira de Botânica 33: 425-436. 
MIGUEL EC, PIREDA S, BARROS CF, ZOTTICH U, GOMES VM, MIGUENS FC \& CUNHA, M. 2017. Outer cell wall structure and the secretion mechanism of colleters of Bathysa nicholsonii K.Schum. (Rubiaceae). Acta Botanica Brasilica 31: 411-419.

MOHAN JSS \& INAMDAR JA. 1986. Ultrastructure and secretion of extrafloral nectaries of Plumeria rubra L. Annals of Botany 57: 389-401.

PAIVA EAS. 2009. Occurrence, structure and functional aspects of the colleters of Copaifera langsdorffii Desf. (Fabaceae, Caesalpinioideae). Comptes Rendus Biologies 332: 1078-1084.

PAIVA EAS. 2016. How do secretory products cross the plant cell wall to be released? A new hypothesis involving cyclic mechanical actions of the protoplast. Annals of Botany Page 1-8.

PAIVA EAS. 2017. How does the nectar of stomata-free nectaries cross the cuticle? Acta Botanica Brasilica 31: 525-530.

PAIVA EAS \& MACHADO SR. 2006. Colleters in Caryocar brasiliense (Caryocaraceae): ontogenesis, ultrastructure and secretion. Brazilian Journal of Biology 66: 301-308.

REYNOLDS ES. 1963. The use of lead citrate at high $\mathrm{pH}$ as an electron opaque stain in electron microscopy. Journal of Cell Biology 17: 208-212.

RIBEIRO JC, FERREIRA MJP \& DEMARCO D. 2017. Colleters in Asclepiadoideae (Apocynaceae): protection of meristems against 
desiccation and new functions assigned. International Journal of Plant Sciences 178: $465-477$

RIO MCS do. 2001. Estudos taxonômicos e anatômicos do gênero Prestonia R. BR. nom. cons. (Apocynaceae). Campinas, Tese de Mestrado, Instituto de Biologia, Universidade Estadual de Campinas.

RIO MCS do. 2006. Estudos anatômicos em espécies de Forsteronia G.Mey. (Apocynaceae) de cerrado. Campinas, Tese de Doutorado, Instituto de Biologia, Universidade Estadual de Campinas.

RIO MCS do, CASTRO M de M \& KINOSHITA LS. 2002. Distribuição e caracterização anatômica dos coléteres foliares de Prestonia coalita (Vell.) Woodson (Apocynaceae). Revista Brasileira de Botânica 25: 339-349.

SCHWARZ E de A \& FURLAN A. 2002. Coléteres foliares de Oxypetalum R.Br. (Asclepiadoideae, Apocynaceae) - aspectos ultraestruturais e anatômicos úteis à taxonomia das espécies do Paraná (Brasil). Acta Biológica Paranaense 31: 79-97.

SENNBLAD B, ENDRESS ME \& BREMER B. 1998. Morphology and molecular data in phylogenetic fraternity: the tribe Wrightieae (Apocynaceae) revisited. American Journal of Botany 85: 1143-1158.

SIMÕES CMO, SCHENKEL EP, GOSMANN G, MELLO JCP de MENTZ LA \& PETROVICK PR. 2004. Farmacognosia: da planta ao medicamento. $5^{\mathrm{a}}$ ed., Porto Alegre/Florianópolis, Editora da UFRGS/Editora da UFSC. 
THIÉRY JP. 1967 Mise en évidence des polysaccharides sur coupes fines en microscopie électronique. Journal de Microscopie 6: 987-1018.

THOMAS V. 1991 Structural, functional and phylogenetic aspects of the colleter. Annals of Botany 68: 287-305.

THOMAS V \& DAVE Y. 1989a. The colleters of Alstonia scholaris L. (Apocynaceae). Indian Botanical Contactor 6: 25-29.

THOMAS V \& DAVE Y. 1989b. Structure, origin, development and senescence of colleters in Nerium indicum Mill. (N. odorum Soland., Apocynaceae). Korean Journal of Botany 32: 163-172.

THOMAS V, DAVE Y \& MENON ARS. 1989. Anatomy and histochemistry of colleters in Roupelia grata Wall. (Apocynaceae). Nordic Journal of Botany 8: 493-496.

WATSON ML. 1958. Staining of tissue sections for electron microscopy with heavy metals. Journal of Biophysical and Biochemical Cytology 4: 475. 